\title{
Reduced Expression of Tn10-mediated Tetracycline Resistance in Escherichia coli Containing More Than One Copy of the Transposon
}

\author{
By IAN CHOPRA, * STUART W. SHALES, JOHN M. WARD† AND \\ LINDA J. WALLACE† \\ Department of Bacteriology, University of Bristol, Bristol BS8 1TD, U.K.
}

(Received 26 November 1980; revised 20 February 1981)

In Escherichia coli a single copy of Tn 10 confers high-level resistance to tetracycline.
Resistance itself results from expression of three distinct mechanisms which normally act
together (Shales et al., 1980). In cells containing two copies of Tn 10 , the level of resistance to
tetracycline was reduced. This was not due to overproduction of the repressor which controls
the resistance genes, because strains diploid for an operator-constitutive allele of Tn 10 also
exhibited reduced expression of resistance. The negative gene dosage effect resulted from
decreased expression of two mechanisms ( 1 and 2 ) consequent on enhanced expression of the
third mechanism. The net result of increasing the copy number was a decrease in resistance
because mechanism 3 was less efficient than mechanisms 1 and 2 in protecting the cell against
tetracycline. The DNA sequence responsible for the reduced expression of resistance was
contained in the internal BglII fragment of Tn 10 . This sequence, which is probably unique to
Tn10, may encode the protein which mediates mechanism 3 . Elevated levels of this protein
probably cause decreased expression of mechanisms 1 and 2 .

\section{INTRODUCTION}

Gene amplification of plasmid-located antibiotic resistance determinants frequently leads to increased levels of antibiotic resistance. For instance, an increase in gene dosage leads to greater resistance to ampicillin, chloramphenicol and streptomycin (Nordstrom et al., 1972; Uhlin \& Nordstrom, 1975, 1977). There is a similar relationship for several tetracycline resistance determinants. When the plasmid pSC101, present at 5 copies per chromosome, is linked to ColE1 to produce a hybrid plasmid with a copy number of 16 there is a concomitant increase in tetracycline resistance (Cabello et al., 1976). The tetracycline resistance determinant on plasmid pRSD1 is located in a transposon designated Tn 1721 (Schmitt et al., 1979). Growth of Escherichia coli harbouring pRSD1 in the presence of tetracycline leads to an increase in the copy number of the transposon and increased expression of resistance (Mattes et al., 1979; Schmitt et al., 1979). Cloning of the tetracycline resistance determinant of RP1 ( 2 copies per chromosome) into a derivative of RSF2124 (30 copies per chromosome) produces a 3 -fold increase in the level of resistance to tetracycline (P. M. Bennett, I. Chopra \& S. W. Shales, unpublished data).

In some cases, plasmid-determined tetracycline resistance is encoded by a transposon termed Tn 10 that is 9300 base pairs long (Jorgensen \& Reznikoff, 1979). In contrast to the above findings, Taylor et al. (1977) found that multiple copies of Tn 10 per cell, obtained by generating a copy number mutant of NR1 (pRR12), led to a decrease in resistance of $E$. coli carrier strains compared with cells harbouring wild-type NR1. Since expression of

† Present address: Department of Biochemistry, University of Manchester Institute of Science and Technology, P.O. Box 88, Manchester M60 1QD, U.K. 
Tn10-mediated tetracycline resistance is subject to negative regulatory control (Yang et al., 1976), resistance conferred in $E$. coli by pRR12 $\left(3 \mu \mathrm{g} \mathrm{ml}^{-1}\right)$ relative to NR1 $\left(100 \mu \mathrm{g} \mathrm{ml}^{-1}\right)$ might result from a higher level of tetracycline gene repressor owing to a repressor gene dosage effect (see discussion in Jorgensen \& Reznikoff, 1979). However, this is an unlikely explanation because expression of resistance coded for by the determinants in pSC101, pRSD 1 and RP1, all of which show positive gene dosage effects, is also probably subject to negative regulatory control (Chopra \& Howe, 1978; Mattes et al., 1979; Shales et al., 1980; P. M. Bennett, unpublished data).

Whether a tetracycline resistance determinant shows a positive or a negative gene dosage response may be related to the nature of the structural genes it carries. Thus, the resistance region of $\mathrm{Tn} 10$, which shows a negative response, is genetically distinct from the resistance determinants in pSC101, pRSD1 and RP1 (Mendez et al., 1980), each of which shows a positive response. The lack of nucleotide sequence homology between the resistance region of Tn10 and the other determinants clearly implies that the products of $\operatorname{Tn} 10$ differ from those encoded by the other plasmids. Recent studies on expression of Tn10-mediated resistance (Beck, 1979; Shales et al., 1980) imply that resistance results from the interplay of at least three separate resistance mechanisms each of which may be mediated by separate proteins. To understand fully the negative gene dosage response associated with Tn 10 it seems necessary to examine expression of each of the three resistance mechanisms as a function of Tn10 copy number. Unfortunately the products that mediate the three mechanisms have not yet been unequivocally identified and so cannot be quantified. However, it is possible to determine expression of the resistance mechanisms from phenotypic studies (Shales et al., 1980). The phenotypes associated with these mechanisms are as follows (Ball et al., 1980; Shales et al., 1980):

(a) A 10- to 20-fold increase in resistance to tetracycline that is not associated with decreased antibiotic accumulation - mechanism 1.

(b) A 4- to 7-fold increase in resistance to tetracycline that is associated with decreased uptake of the antibiotic - mechanism 2. This mechanism results at least partially from accelerated efflux of the drug from resistant bacteria.

(c) A 2-to 3-fold increase in resistance to both tetracycline and its derivative minocycline, that is not associated with decreased accumulation of either antibiotic-mechanism 3.

With wild-type Tn10 derived from R100-1, mechanisms 2 and 3 are inducible by tetracycline whereas mechanism 1 is expressed constitutively (Shales et al., 1980). We have now examined expression of these phenotypes in strains having different numbers of Tn 10 per cell in the hope that we might clarify the basis of the negative gene dosage response exhibited by $\operatorname{Tn} 10$.

\section{METHODS}

Bacterial strains and plasmids. The Escherichia coli strains and plasmids used are listed in Table 1. Some of the plasmids were specifically constructed for this study and their genealogy is described in Figs 1 and 2. Plasmids were constructed according to the methods of Ward \& Grinsted (1978), except that buffers were changed after precipitation of DNA by ethanol instead of being removed by dialysis.

General methods. Determination of concentrations of antibiotic causing a $50 \%$ reduction in growth rate $\left(\mathrm{IC}_{50}\right)$, estimation of covalently closed circular plasmid DNA content and determination of the accumulation of tetracycline by spectrofluorimetry were performed as described previously (Ball et al., 1980; Shales et al., 1980).

\section{RESULTS}

\section{Possible role of repressor in reduced expression of Tn10-mediated tetracycline resistance}

The availability of mutants of Tn 10 which express resistance constitutively (Foster, 1977) provides a means to determine whether the tetracycline gene repressor has a role in reducing resistance in the multicopy state. The plasmids pDU300 and pDU301 are reported to contain 
Table 1. Escherichia coli K12 strains and plasmids

\begin{tabular}{|c|c|c|c|}
\hline Strain & Strain description & Plasmid markers* & Reference/source \\
\hline JC3272 & his trp lys strA & & Achtman et al. (1971) \\
\hline DU1200 & $\begin{array}{l}\text { Transposition of } \mathrm{Tn} 10 \text { from } \\
\text { pDU300 to the chromosome } \\
\text { of JC3272 }\end{array}$ & & Foster (1977) \\
\hline DU1203 & $\begin{array}{l}\text { Transposition of } \mathrm{Tn} 10 \text { from } \\
\text { pDU301 to the chromsome } \\
\text { of JC3272 }\end{array}$ & & Foster (1977) \\
\hline DU3091 & $\begin{array}{l}\text { Transposition of } \operatorname{Tn} 10 \text { from } \\
\text { R } 100-1 \text { to the chromosome } \\
\text { of JC } 3272\end{array}$ & & Foster et al. (1975) \\
\hline UB 1528 & JC3272(pIP7) & $\mathrm{Tc} \mathrm{Km} \mathrm{Sm} \mathrm{Su}$ & Shales et al. (1980) \\
\hline UB 1529 & JC3272(pIP69) & $\mathrm{Tc} \mathrm{Km} \mathrm{Cb}$ & Shales et al. (1980) \\
\hline UB 1533 & JC3272(R100-1) & $\mathrm{Tc} \mathrm{Cm} \mathrm{Sm} \mathrm{Hg}$ & Foster et al. (1975) \\
\hline UB 1553 & $\mathrm{JC} 3272(\mathrm{pDU} 301)$ & $\mathrm{Tc} \mathrm{Cm} \mathrm{Sm} \mathrm{Hg}$ & Shales et al. (1980) \\
\hline UB5793 & DU3091(R 100-1) & $\mathrm{Tc} \mathrm{Cm} \mathrm{Sm} \mathrm{Hg}$ & This paper \\
\hline UB6012 & JC3272(pUB5554) & $\mathrm{Tc} \mathrm{Tp} \mathrm{Su}$ & This paper \\
\hline UB6014 & JC3272(pUB5555) & $\mathrm{Tc} \mathrm{Tp}$ & This paper \\
\hline UB6121 & DU1203(pDU301) & $\mathrm{Tc} \mathrm{Cm} \mathrm{Sm} \mathrm{Hg}$ & This paper \\
\hline UB6 122 & DU1203(pIP7) & $\mathrm{Tc} \mathrm{Km} \mathrm{Sm} \mathrm{Su}$ & This paper \\
\hline UB6 123 & JC3272(pUB1640) & Tc Tp & This paper \\
\hline UB6124 & JC3272(pUB1641) & $\mathrm{Tc} \mathrm{Tp}$ & This paper \\
\hline UB6 125 & DU1203(pUB1640) & Tc Tp & This paper \\
\hline UB6126 & DU1 203(pUB 1641) & $\mathrm{Tc} \mathrm{Tp}$ & This paper \\
\hline UB6 127 & DU1203(pUB5556) & $\mathrm{Tp}$ & This paper \\
\hline UB6128 & DU1203(pUB5572) & $\mathrm{Tp}$ & This paper \\
\hline UB6129 & DU1203(pUB5502) & $\mathrm{Tp}$ & This paper \\
\hline
\end{tabular}

* Resistance respectively to carbenicillin $(\mathrm{Cb})$, chloramphenicol $(\mathrm{Cm})$, kanamycin $(\mathrm{Km})$, mercuric ions $(\mathrm{Hg})$, tetracycline $(\mathrm{Tc})$, trimethoprim $(\mathrm{Tp})$, streptomycin $(\mathrm{Sm})$ and sulphonamide $(\mathrm{Su})$.

operator-constitutive $\left(\mathrm{O}^{\mathfrak{c}}\right)$ mutants of $\operatorname{Tn} 10$ (Foster, 1977). We confirmed the constitutive phenotypes conferred by these plasmids since exposure of strain UB1553, which carries pDU301, to sub-inhibitory concentrations of tetracycline failed to increase resistance (Table 2). Furthermore, expression of resistance in a strain (DU1200) in which the constitutive $\left(\mathrm{O}^{\mathrm{c}}\right)$ derivative of Tn 10 had transposed from pDU300 to the chromosome of JC3272 (Foster, 1977) was also constitutive (Table 2). In contrast, both strains UB 1533 and DU3091, each of which contains wild-type Tn 10, exhibited inducible resistance to tetracycline (Table 2).

Plasmid pDU301 was transferred to strain DU1203 to produce strain UB6121, which carries constitutive alleles of $\mathrm{Tn} 10$ in both chromosomal and plasmid locations (Table 1). Its level of resistance to tetracycline was less than that exhibited by cells carrying a determinant in one location only (Table 2). The reduction in resistance cannot be attributed to accumulation of repressor because exposure to a sub-inhibitory level of tetracycline $(0.5 \mu \mathrm{g}$ $\mathrm{ml}^{-1}$ ) did not enhance resistance (Table 2).

Further evidence that repressor is not involved in lowering resistance was provided by experiments in which the plasmid R100-1 was introduced into strain DU3091 to produce strain UB5793, which therefore carried wild-type Tn10 in both chromosomal and plasmid locations. Its level of resistance to tetracycline following exposure to $0.5 \mu \mathrm{g}$ tetracycline $\mathrm{ml}^{-1}$ was less than that exhibited by DU3091 which carries the determinant in one location only (Table 2). Prior exposure of strain UB5793 to higher concentrations of tetracycline (1.0 and $5.0 \mu \mathrm{g} \mathrm{ml}^{-1}$ ) failed to increase further its level of resistance to tetracycline (data not shown), which was therefore still lower than that of induced cultures of DU3091. Again, these results showed that the reduction in resistance cannot be attributed to accumulation of functional repressor molecules. 


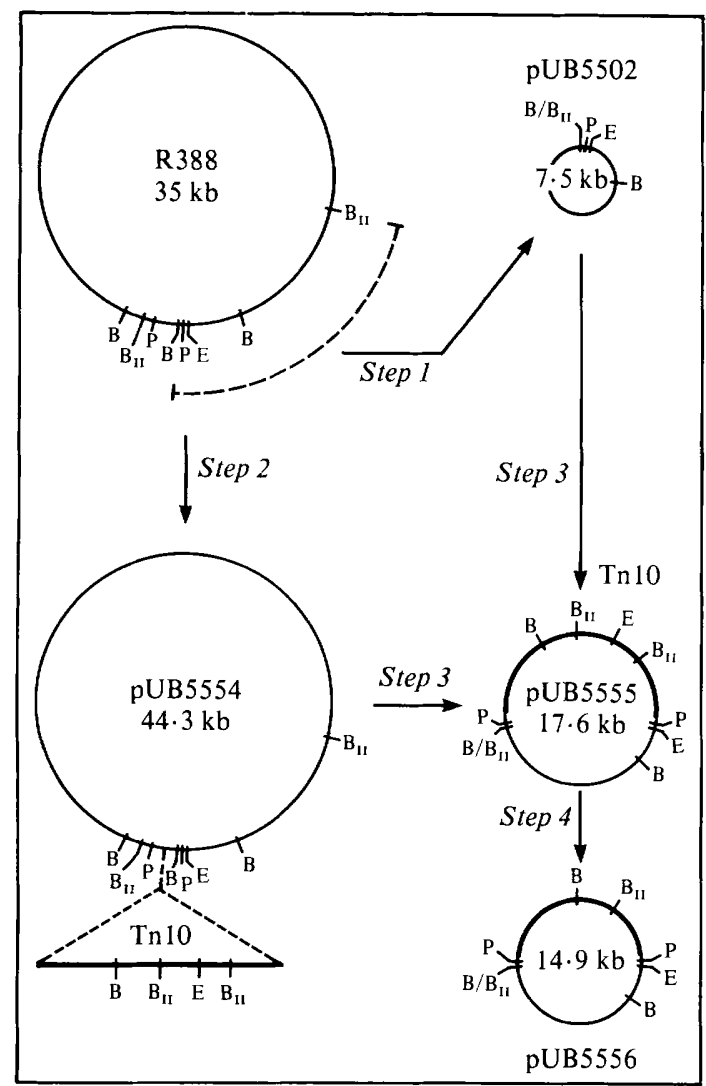

Fig. 1

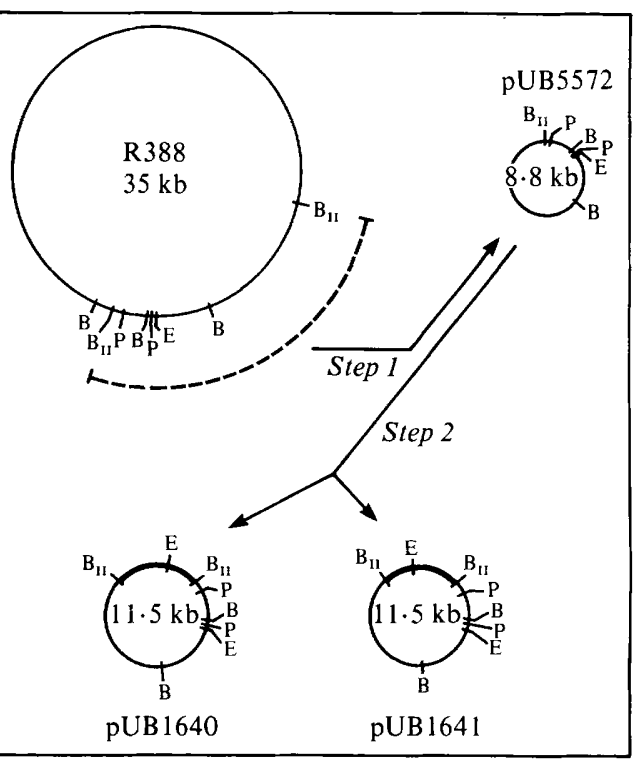

Fig. 2

Fig. 1. Construction of plasmids pUB5502, pUB5554, pUB5555 and pUB5556. Step 1: formation of pUB5502 from R388 as described previously (Ward \& Grinsted, 1978). Step 2: transposition of Tn 10 from the chromosome of DU1200 into the small $(1 \mathrm{~kb})$ Pst I fragment of R388 to form pUB5554 (R388:: Tn 10). Step 3: ligation of the PstI fragment of pUB5554, containing Tn 10, into the single PstI site of pUB5502 to form pUB5555. Step 4: deletion in vitro, using $B g / \mathrm{II}$, of DNA between the $B g / \mathrm{II}$ sites of Tn 10 in pUB5555, resulting in the formation of pUB5556 which has lost the $2.7 \mathrm{~kb} B g l \mathrm{II}$ fragment of Tn10. Plasmid pUB5554 has a copy number of 3 per chromosome and pUB5555, 8 per chromosome. Abbreviations for restriction endonucleases: B, BamHI; B $\mathrm{II}$, BglII; E, EcoRI; P, PstI. (kb denotes $10^{3}$ base pairs.)

Fig. 2. Construction of plasmids pUB5572, pUB1640 and pUB1641. Step 1: digestion of R388 with $B g l I I$ to form pUB5572. Step 2: cloning of the $2.7 \mathrm{~kb} \mathrm{BglII}$ fragment from pUB5555 (Fig. 1) into the BglII site of pUB5572 in both orientations to give pUB1640 and pUB1641. Abbreviations for restriction endonucleases: B, BamHI: $\mathrm{B}_{\mathrm{II}}$, BglII; E, EcoRI; P, PstI.

\section{Reduced expression of tetracycline resistance in Tn10 diploids occurs after induction}

Tetracycline resistance in uninduced cultures of strain UB5793 (containing 2 copies per chromosome of wild-type Tn10) was the sum of the basal levels expressed in the hosts (UB1533 and DU3091) containing only a single copy of Tn10 (Table 2). We attribute this to a positive gene dosage effect for mechanism 1. Induction of UB1533 and DU3091 led, respectively, to 10- and 5-fold increases in tetracycline resistance (Table 2). Similar treatment of UB5793 led only to a 2-fold increase (Table 2). Therefore, the mechanism which reduced resistance when 2 copies of $\operatorname{Tn} 10$ were present was inducible by tetracycline. 
Table 2. Expression of tetracycline resistance in strains of E. coli K12 containing wild-type and constitutive derivatives of Tn10

\begin{tabular}{|c|c|c|c|c|c|}
\hline \multirow[b]{3}{*}{ Strain } & & & \multirow{3}{*}{$\begin{array}{c}\text { Mean no. of } \\
\text { Tn } 10 \text { copies } \\
\text { per chromosome }\end{array}$} & \multicolumn{2}{|c|}{$\begin{array}{l}\text { Resistance level }\left(\mathrm{IC}_{50}\right) \text { to } \\
\text { tetracycline }\left(\mu \mathrm{g} \mathrm{ml}^{-1}\right) \S\end{array}$} \\
\hline & \multicolumn{2}{|c|}{ Tetracycline resistance genes $\dagger$} & & Growth & Growth \\
\hline & Plasmid & Chromosomal & & without Tc & with Tc\| \\
\hline JC3272* & - & - & - & $0.29 \pm 0.02$ & - \\
\hline UB 1553 & pDU301 $\left(\mathrm{O}^{\mathrm{c}}\right)$ & - & 1 & $61.0 \pm 1.0$ & $63.0 \pm 0.9$ \\
\hline DU1200 & - & From pDU300 $\left(\mathrm{O}^{\mathrm{c}}\right)$ & 1 & $71 \cdot 5 \pm 3 \cdot 5$ & $73 \cdot 0 \pm 2 \cdot 0$ \\
\hline UB6121 & pDU301 $\left(\mathrm{O}^{\mathrm{c}}\right)$ & From pDU301 $\left(\mathrm{O}^{c}\right)$ & 2 & $51 \cdot 8 \pm 0 \cdot 8$ & $53 \cdot 0 \pm 1 \cdot 4$ \\
\hline UB1533 & R100-1 (WT) & - & 1 & $3.05 \pm 0.05$ & $30.8 \pm 0.3$ \\
\hline DU3091 & - & From R100-1 (WT) & 1 & $11.8 \pm 0.4$ & $58.0 \pm 8.5$ \\
\hline UB5793 & R100-1 (WT) & From R100-1 (WT) & 2 & $15 \cdot 3 \pm 1 \cdot 3$ & $31 \cdot 0 \pm 0.5$ \\
\hline
\end{tabular}

* JC3272 is the tetracycline-sensitive, plasmid-free, parent of all other strains.

$\dagger \mathrm{WT}$ and $\mathrm{O}^{\mathrm{c}}$ refer to wild-type (WT) Tn10, in which expression of resistance is inducible, and operator constitutive $\left(\mathrm{O}^{\mathrm{c}}\right)$ Tn 10 mutants.

$\ddagger$ Plasmid copy numbers determined as described by Shales et al. (1980).

$\S$ Mean values \pm 1 standard deviation.

II Strains pre-grown for at least 10 generations in the presence of $0.5 \mu \mathrm{g}$ tetracycline $\mathrm{ml}^{-1}$.

\section{Nature of the product mediating reduced expression in strains carrying more than one copy of Tn10}

Reduced expression of resistance in the Tn10 diploid UB5793 occurred after induction thereby implicating a product of the Tn10 structural genes in the effect. The response could therefore be mediated either by the product conferring mechanism 2 , or that necessary for mechanism 3, because both mechanisms of resistance are inducible in $\mathrm{Tn} 10$ derived from wild-type R100-1 (Shales ot al., 1980).

The plasmid pIP7 was used to investigate the possible role of a mechanism 2 product in the negative gene dosage effect of Tn10. Plasmid pIP7 (with a copy number of 2 per chromosome) mediates resistance to tetracycline but not minocycline (Table 3), and induction of resistance leads only to decreased accumulation of tetracycline (Shales et al., 1980). The pIP7-encoded product that confers decreased accumulation is functionally, but probably not structurally, analogous to that determined by Tn 10 (Ball et al., 1980; Mendez et al., 1980; Shales et al., 1980). Inducible products of pIP7 did not reduce the expression of Tn 10-mediated resistance to tetracycline or minocycline (Table 3), thereby implying that the pIP7 product mediating mechanism 2 did not decrease the expression of Tn 10-determined resistance.

Because the reduction in resistance in the Tn10 diploids was probably caused by the synthesis of the product required for joint resistance to tetracycline and minocycline (i.e. mechanism 3), we attempted to produce a Tn 10 derivative in which the structural gene for the joint resistance mechanism was deleted, but which still encoded a functional mechanism 2. Jorgensen \& Reznikoff (1979) concluded that the structural gene for a 36 kilodalton (36K) envelope protein (probably mediating mechanism 2) resides mainly within an internal 2025 base pair (bp) fragment of Tn 10 produced by cleavage with $\mathrm{HpaI}$ (see Fig. 4). The Tn10 fragment generated by digestion with $B g l I I$ should therefore contain the structural gene for the $36 \mathrm{~K}$ protein (Jorgensen \& Reznikoff, 1979), but might lack the gene required for expression of mechanism 3. Plasmids pUB 1640 and pUB1641 were therefore constructed which contain the internal $B g l$ II fragment of Tn 10 cloned in opposite orientations (Fig. 2).

Both plasmids conferred decreased accumulation of tetracycline (Table 4) consistent with a role for the $36 \mathrm{~K}$ protein in mechanism 2 . However, the recombinant plasmids were not deleted for mechanism 3 because they encoded minocycline resistance (Table 4). The extent to which mechanism 2 was expressed by these plasmids was inversely related to the level of 

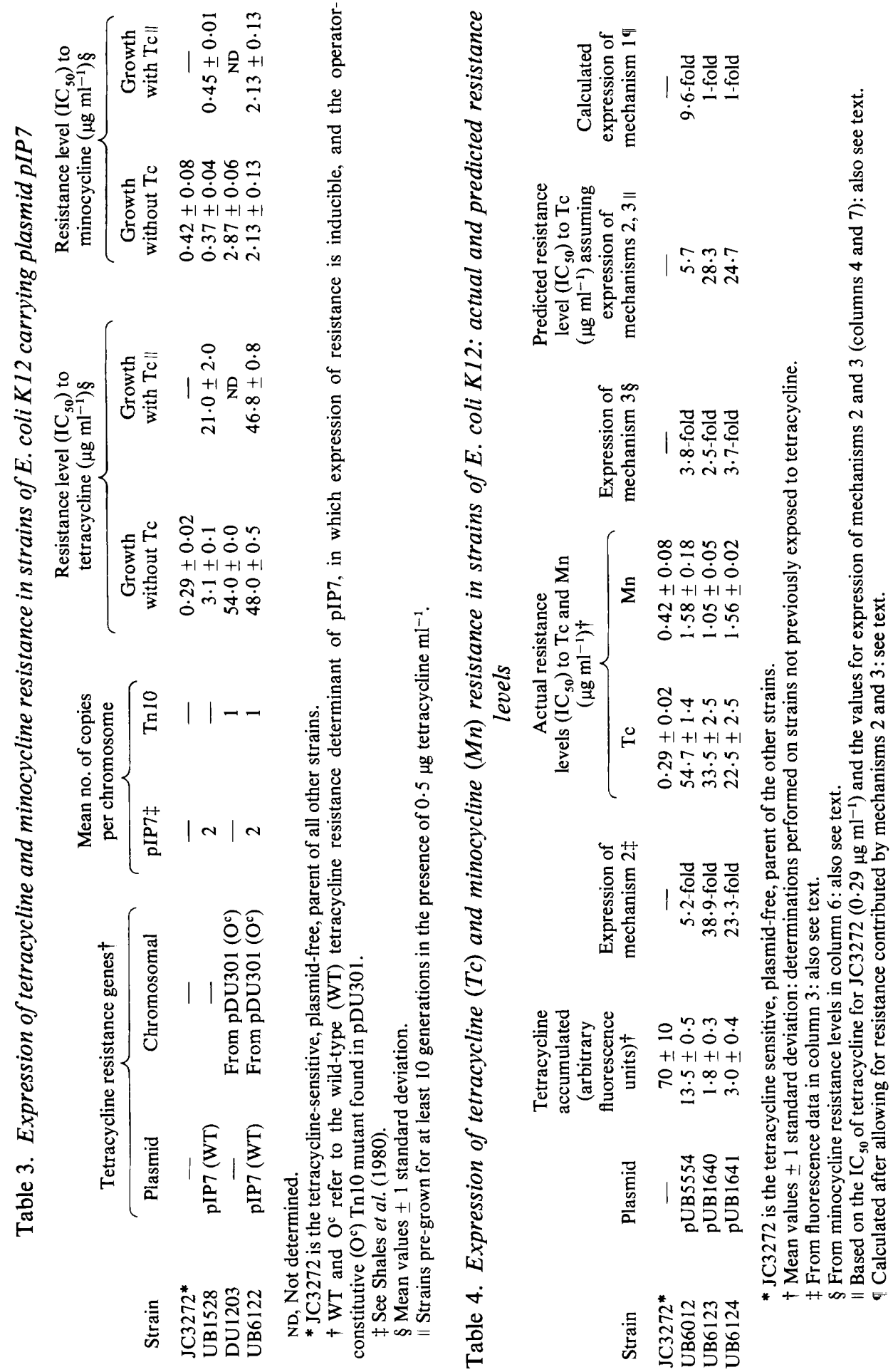


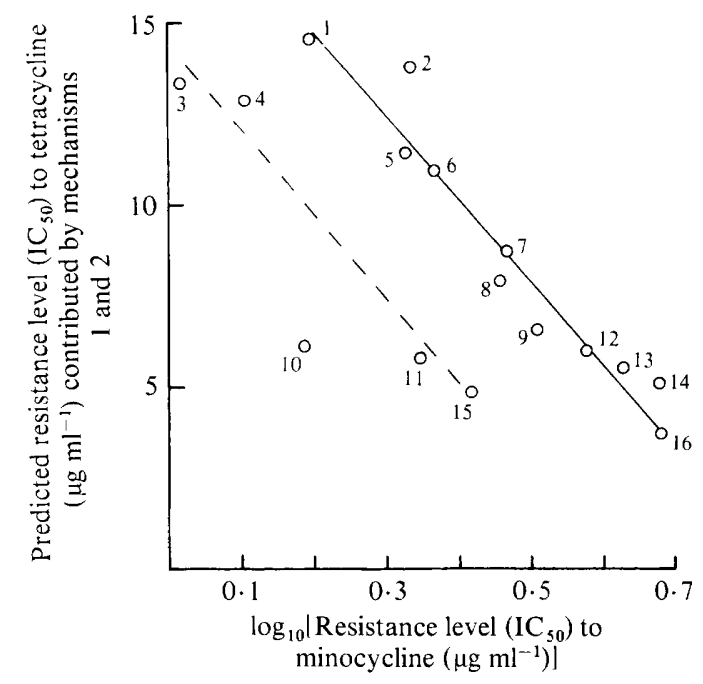

Fig. 3. Relationship between the predicted expression of the Tn10-encoded resistance mechanisms 1 and 2, and the level of minocycline resistance (mechanism 3). Strains containing Tn 10 or genes derived from Tn 10 were examined for expression of three proposed resistance mechanisms (see text and Shales et al., 1980). Expression of mechanism 2 was determined from fluorescence data and mechanism 3 from the level of resistance $\left(\mathrm{IC}_{50}\right)$ to minocycline. Any residual resistance to tetracycline after accounting for mechanisms 2 and 3 was attributed to expression of mechanism 1 (see text and Table 4).

Key to strains: (1) UB6012, (2) DU1200, (3) UB6123, (4) UB6014, (5) DU3091, (6) UB1553, (7) UB6127, (8) DU1203, (9) UB6128, (10) UB6124, (11) UB5793, (12) UB6129, (13) UB6125, (14) UB1529, (15) UB1533, (16) UB6126.

resistance to minocycline (Table 4). Thus, the ratio of minocycline resistance levels for UB6124:UB6123 was 1.5 and the ratio of tetracycline accumulation for UB6124:UB6123 was 1.7 . The data therefore support the notion that the product involved in resistance to minocycline (mechanism 3) can affect the expression of mechanism 2.

\section{Expression of mechanisms 1 and 2 is inversely related to that of mechanism 3}

Data presented in the previous sections imply that elevated levels of the mechanism 3 product conferring joint resistance to tetracycline and minocycline can lead to reduced expression of mechanism 2. However, some simple calculations (see below) predicted that expression of mechanism 1 might also be affected by the mechanism 3 product.

If expression of both mechanisms 1 and 2 is inversely related to that of mechanism 3 we would predict a negative correlation between expression of mechanisms 1 and 2 together and mechanism 3. To test this possible relationship, additional data were collected for strains containing Tn10 and were combined with results already presented. In each case expression of mechanisms 1, 2 and 3 was determined. Expression of mechanism 3 was obtained directly from the $\mathrm{IC}_{50}$ data for minocycline. Expression of mechanism 2 was calculated using data from fluorimeter traces. For example, expression of mechanism 2 in UB6012 was estimated as follows: strain UB6012 accumulated 13.5 units of tetracycline whereas strain JC3272 (the plasmid-free host) accumulated 70 units, and so expression of mechanism 2 in UB6012 was $70 / 13 \cdot 5$, or $5 \cdot 2$-fold (Table 4 ). If mechanism 2 only was expressed it would result in cells with an $\mathrm{IC}_{50}$ of $1.5 \mu \mathrm{g}$ tetracycline $\mathrm{ml}^{-1}$ [i.e. $5.2 \times\left(\mathrm{IC}_{50}\right.$ of tetracycline for JC3272) $=5.2 \times$ $0.29 \mu \mathrm{g} \mathrm{ml}^{-1}$ ]. Expression of mechanism 1 was calculated from the total level of resistance to tetracycline after accounting for expression of mechanisms 2 and 3. For strain UB6012, for example, mechanism 2 contributed a 5.2-fold increase in resistance and mechanism 3 a $3 \cdot 8$-fold increase [i.e. $\left(\mathrm{IC}_{50}\right.$ of minocycline for $\left.\mathrm{UB6012}\right) /\left(\mathrm{IC}_{50}\right.$ of minocycline for $\left.\mathrm{JC} 3272\right)=$ 
$1 \cdot 58 / 0.42$, and so we predict that these mechanisms alone would produce cells with an $\mathrm{IC}_{50}$ of $5.7 \mu \mathrm{g}$ tetracycline $\mathrm{ml}^{-1}$ [i.e. $5.2 \times 3.8 \times\left(\mathrm{IC}_{50}\right.$ of tetracycline for JC3272) $=5.2 \times 3.8 \times$ $0.29 \mu \mathrm{g} \mathrm{ml}^{-1}$ ] (Table 4). Since the actual $\mathrm{IC}_{30}$ of tetracycline for UB6012 was $54.7 \mu \mathrm{g} \mathrm{ml}^{-1}$ (Table 4), we predict that expression of mechanism 1 in UB6012 contributed a 9.6-fold increase in resistance to tetracycline (i.e. 54.7/5.7). Calculated values for expression of mechanism 1 in other strains varied between 10 -fold and 1-fold (i.e. not expressed). Strains UB6123 and UB6124 are examples of bacteria which did not appear to express mechanism 1 (Table 4).

In Fig. 3, data for a variety of strains containing Tn10 are plotted as the theoretical resistance levels conferred by mechanisms 1 and 2 alone versus the logarithm of the minocycline $\mathrm{IC}_{50}$ (i.e. resistance conferred by mechanism 3 ). Two parallel lines were obtained which imply a negative correlation between expression of mechanisms 1 and 2 together and mechanism 3. One group of strains (dashed line) was more sensitive to minocycline. The basis of this difference between the two groups is not known.

\section{DISCUSSION}

While the work described here was in progress, Jorgensen \& Reznikoff (1979) provided data from which it can also be concluded that the repressor is not involved in reducing the level of resistance in strains containing more than one copy of Tn10. The repressor is also unlikely to be involved because the ratio between its content and the number of operator regions with which it interacts should not change with alterations in Tn 10 copy number.

As noted in the Introduction, Tn10-mediated resistance results from the interplay of at least three separate resistance mechanisms, each of which may be mediated by separate Tn10-encoded proteins. Mechanism 2, involving energy-dependent efflux of tetracycline, is likely to be mediated by a $36 \mathrm{~K}$ protein located in the cytoplasmic membrane (Chopra et al., 1981), whereas mechanism 3 may involve protection of ribosomes by a $15 \mathrm{~K}$ protein (Levy et al., 1977; Levy \& McMurry, 1978). The nature of the product mediating mechanism 1 is unknown. From the data presented here we conclude that increased expression of resistance to minocycline (mechanism 3) leads to decreased expression of the other mechanisms (mechanisms 1 and 2). Although enhanced expression of mechanism 3 should lead per se to an increase in resistance to tetracycline, the overall level of resistance falls because mechanisms 1 and 2, which are more efficient than mechanism 3, are suppressed.

If the $\operatorname{Tn} 10$ protein which mediates minocycline resistance caused lowered resistance in the multicopy state, then those tetracycline resistance determinants which show a positive gene dosage effect should not encode resistance to minocycline. This is true for pSC101, RP1 (Mendez et al., 1980; Shales et al., 1980) and pRSD1 (I. Chopra, unpublished data). Extrapolation of the continuous line in Fig. 3 to the point where the theoretical expression of mechanism 3 is 1 -fold [i.e. $\log _{10}\left(\right.$ minocycline $\left.\mathrm{IC}_{50}\right)=-0.38$ ] gives an $\mathrm{IC}_{50}$ value of $29 \mu \mathrm{g}$ tetracycline $\mathrm{ml}^{-1}$ for the combined expression of mechanisms 1 and 2 . This corresponds closely to the levels of tetracycline resistance mediated by the determinants in pIP7 and RP1, neither of which confers minocycline resistance (Shales et al., 1980).

Decreased expression of mechanisms 1 and 2 when $\mathrm{Tn} 10$ is present in several copies might be the consequence of reduced transcription of the respective resistance genes. This model therefore suggests that, in addition to its role in mediating resistance, the mechanism 3 product may bind to DNA and regulate transcription. As yet, there is no evidence to support this contention.

Data presented here, in conjunction with reports by Jorgensen et al. (1978), Jorgensen \& Reznikoff (1979) and Beck (1979), permit conclusions to be drawn on the organization of genes within the resistance region of $\mathrm{Tn} 10$ (Fig. 4). The gene for the $36 \mathrm{~K}$ protein (probably mediating mechanism 2) resides within the HincII fragment of $1275 \mathrm{bp}$ and the structural gene for the repressor lies to the left of this within the HincII fragment of 695 bp (Jorgensen \& 


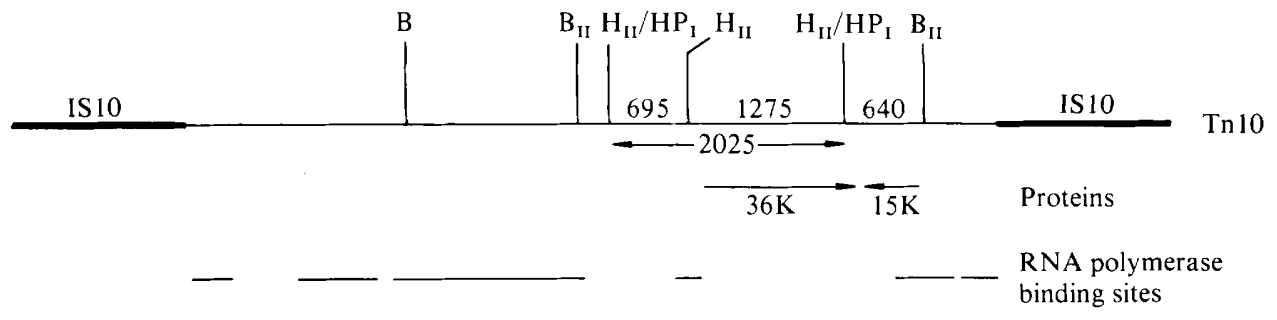

Fig. 4. Transcriptional and restriction site map of the resistance region of $\operatorname{Tn} 10$. The vertical lines above the linear map show some of the restriction endonuclease cleavage sites located in $\operatorname{Tn} 10:$ the lengths of various regions are given in base pairs. Below the linear map the regions which probably code for the $36 \mathrm{~K}$ and $15 \mathrm{~K}$ resistance proteins are indicated, together with their directions of transcription. Horizontal lines designate the general location of RNA polymerase binding sites. The model is compiled from data presented in this paper and by Jorgensen et al. (1978), Jorgensen et al. (1979), Jorgensen \& Reznikoff (1979), Beck (1979) and Shales et al. (1980). Abbreviations for restriction endonucleases: B, Bam HI; $\mathrm{B}_{\mathrm{II}}, B g l \mathrm{II} ; \mathrm{H}_{\mathrm{II}}$, HincII; $\mathrm{HP}_{\mathrm{I}}, H p a \mathrm{I}$.

Reznikoff, 1979). Plasmids pUB1640 and pUB1641 contain both these fragments and additional sequences at either end. The gene conferring joint resistance to tetracycline and minocycline (mechanism 3 ) and probably coding for the $15 \mathrm{~K}$ protein (see above) may not be transcribed from a promoter within the $B g I I I$ fragment because the expression of minocycline resistance conferred by plasmids pUB 1640 and pUB 1641 is affected by the orientation of the $B g l$ II fragment. In plasmids pUB 1640 and pUB 1641 transcription of the $15 \mathrm{~K}$ protein may therefore be mediated by $\mathrm{R} 388$ promoters that are weaker than the normal $\mathrm{Tn} 10$ promoter. The structural gene for the $15 \mathrm{~K}$ protein may therefore reside to the right of the HincII fragment of $1275 \mathrm{bp}$ and its promoter may be located within or to the right of the $B g$ lII cut site on the right of the transposon. Jorgensen \& Reznikoff (1979) concluded that the sequence coding for the carboxy-terminus of the $36 \mathrm{~K}$ protein probably lies within $100 \mathrm{bp}$ of the HincII/HpaI site that defines the right hand side of the $2025 \mathrm{bp}$ fragment (Fig. 4). The gene encoding minocycline resistance may therefore be located in a $540 \mathrm{bp}$ sequence, lying within

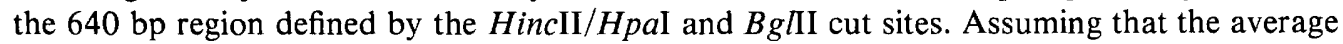
molecular mass of an amino acid is 115 , than a $15 \mathrm{~K}$ protein will require a coding sequence of about 400 bp (Chopra \& Howe, 1978), a length consistent with the size of the region thought to contain the structural gene. Jorgensen \& Reznikoff (1979) concluded that the product effecting the multicopy response is coded by a region of Tn 10 lying to the right of the $640 \mathrm{bp}$ region defined by the HincII/HpaI and BglII cut sites shown in Fig. 4. We believe that this region contains the promoter for the $15 \mathrm{~K}$ protein rather than the structural gene. However, the data of Jorgensen \& Reznikoff (1979) is still consistent with our model because deletions to the right of the $640 \mathrm{bp}$ region in their recombinant plasmids (unrelated to R388) could have eliminated the promoter and abolished synthesis of the $15 \mathrm{~K}$ protein. Our contention that the region to the right of the $640 \mathrm{bp}$ fragment contains a promoter is also consistent with data showing an RNA polymerase binding site close to the insertion sequence at the right hand side of Tn 10 (see Fig. 4).

Support for this work was provided by a programme grant from the Medical Research Council to Professor M. H. Richmond, and by project grants from the Medical Research Council to I.C. We thank Mrs E. Barratt for excellent technical assistance.

\section{REFERENCES}

Achtman, M., Willetts, N. \& Clark, A. J. (1971). Beginning a genetic analysis of conjugational transfer determined by the F factor in Escherichia coli by isolation and characterization of transfer-deficient mutants. Journal of Bacteriology 106, 529-538.
Ball, P. R., Shales, S. W. \& Chopra, I. (1980). Plasmid-mediated tetracycline resistance in Escherichia coli involves increased efflux of the antibiotic. Biochemical and Biophysical Research Communications 93, 74-81. 
BECK, C. F. (1979). A genetic approach to the analysis of transposons. Proceedings of the National Academy of Sciences of the United States of America 76, 2376-2380.

Cabello, F., Timmis, K. \& Cohen, S. N. (1976). Replication control in a composite plasmid constructed by in vitro linkage of two distinct replicons. Nature, London 259, 285-290.

Chopra, I. \& Howe, T. G. B. (1978). Bacterial resistance to the tetracyclines. Microbiological Reviews 42, 707-724.

Chopra, I., Ball, P. R., Eccles, S. J. \& Shales, S. W. (1981). Nature and function of Tn10-encoded proteins that mediate tetracycline resistance in Escherichia coli. In Molecular Biology, Pathogenicity, and Ecology of Bacterial Plasmids (in the Press). Edited by S. B. Levy. New York: Plenum Publishing Corp.

Foster, T. J. (1977). Isolation and characterisation of mutants of R100-1 which express tetracycline resistance constitutively. FEMS Microbiology Letters 2, 271-274.

Foster, T. J., Howe, T. G. B. \& Richmond, K. M. V. (1975). Translocation of the tetracycline resistance determinant from R100-1 to the Escherichia coli chromosome. Journal of Bacteriology 124, 11531158.

JoRgENSEN, R. A. \& REZNIKOFF, W. S. (1979). Organization of structural and regulatory genes that mediate tetracycline resistance in transposon $\mathrm{Tn} 10$. Journal of Bacteriology 138, 705-714.

JoRgEnSEN, R. A., BERG, D. \& REZNIKOFF, W. (1978). Genetic organization in the transposable tetracycline resistance determinant Tn10. In Microbiology - 1978, pp. 181-183. Edited by D. Schlessinger. Washington, D.C.: American Society for Microbiology.

Jorgensen, R., Berg, D., Allet, B. \& Reznikoff, W. (1979). A restriction endonuclease cleavage map for the transposable tetracycline resistance determinant Tn10. Journal of Bacteriology 137, 681-685.

Levy, S. B. \& MCMurry, L. (1978). Probing the expression of plasmid-mediated tetracycline resistance in Escherichia coli. In Microbiology 1978, pp. 177-180. Edited by D. Schlessinger. Washington, DC.: American Society for Microbiology.
Levy, S. B., McMurry, L., Onigman, P. \& SAunders, R. M. (1977). Plasmid-mediated tetracycline resistance in Escherichia coli. In Topics in Infectious Diseases, vol. 2, pp. 181-203. Edited by J. Drews \& G. Hogenauer. New York: Springer Verlag.

Mattes, R., Burkardt, H. J. \& SChMitT, R. (1979). Repetition of tetracycline resistance determinant genes on $\mathrm{R}$ plasmid pRSD1 in Escherichia coli. Molecular and General Genetics 168, 173-184.

Mendez, B., Tachibana, C. \& Levy, S. B. (1980). Heterogeneity of tetracycline resistance determinants. Plasmid 3, 99-108.

Nordstrom, K., Ingram, L. C. \& Lundback, A. (1972). Mutations in R factors of Escherichia coli causing an increased number of $\mathrm{R}$-factor copies per chromosome. Journal of Bacteriology 110, 562569.

Schmitt, R., BernhaRd, E. \& MATTES, R. (1979). Characterisation of $\operatorname{Tn} 1721$, a new transposon containing tetracycline resistance genes capable of amplification. Molecular and General Genetics 172, 53-65.

Shales, S. W., Chopra, I. \& Ball, P. R. (1980). Evidence for more than one mechanism of plasmiddetermined tetracycline resistance in Escherichia coli. Journal of General Microbiology 121, 221-229.

TAYLOR, D. P., GReEnberg, J. \& Rownd, R. H. (1977). Generation of miniplasmids from copy number mutants of the R plasmid NR1. Journal of Bacteriology 132, 986-995.

Uhlin, B. E. \& Nordstrom, K. (1975). Plasmid incompatibility and control of replication: copy mutants of the R-factor R1 in Escherichia coli. Journal of Bacteriology 124, 641-649.

Uhlin, B. E. \& Nordstrom, K. (1977). R plasmid gene dosage effects in Escherichia coli $\mathrm{K}$-12: copy mutants of the R plasmid R1 drd-19. Plasmid 1, $1-7$.

WARD, J. M. \& GRINSTED, J. (1978). Mapping of functions in the R-plasmid R388 by examination of deletion mutants generated in vitro. Gene 3, 87-95.

YANG, H. L., ZUBAY, G. \& LeVY, S. B. (1976). Synthesis of an $\mathrm{R}$ plasmid protein associated with tetracycline resistance is negatively regulated. Proceedings of the National Academy of Sciences of the United States of America 73, 1509-1512. 